\title{
Biology of Cloned Cytotoxic T Lymphocytes Specific for Lymphocytic Choriomeningitis Virus: Clearance of Virus and In Vitro Properties $\dagger$
}

\author{
JANET ANDERSON, JACQUELYN A. BYRNE, ROBERT SCHREIBER, STEVEN PATTERSON, \\ AND MICHAEL B. A. OLDSTONE* \\ Department of Immunology, Scripps Clinic and Research Foundation, 10666 North Torrey Pines Road, La Jolla, \\ California 92037
}

Received 22 August 1984/Accepted 2 November 1984

\begin{abstract}
We have generated lymphocytic choriomeningitis virus-specific, H-2-restricted cytotoxic thymus-derived lymphocyte (CTL) clones. By using these reagents in several in vitro assays with infected target cells, we show that CTLs by themselves prevent the release of infectious virus into culture fluids and significantly lower the titers of infectious virus previously produced. This ability of claned CTLs is not influenced by monensin. However, monensin does abrogate the ability of CTLs from spleens of mice primed 6 to 8 days previously with virus to kill virus-infected syngeneic targets. When tested for the participation of lymphokines in this system, the CTLs proliferate when reacted with syngeneic lymphocytic choriomeningitis virus-infected macrophages but fail to make interleukin-2. These CTLs make $\gamma$ interferon when reacted with syngeneic virus-infected targets. However, the production of interferon does not directly correlate with CTL-mediated killing. The number of $\mathrm{H}-2 \mathrm{~K}$ and $\mathrm{D}$ molecules expressed on the target cell surface is not altered during the course of lymphocytic choriomeningitis virus infection. Electron microscopy shows fingerlike projections of the CTL clone thrust into the infected cell and lesions bearing an internal diameter of approximately $15 \mathrm{~nm}$ in those membranes, illustrating the lytic process.
\end{abstract}

Cytotoxic thymus-derived lymphocytes (CTLs) are of interest to virologists because they represent a major force in the control of virus infections. Since their initial description $(12,50,51)$, and establishment of their regulation by genes within the major histocompatibility complex (49), a wide variety of DNA and RNA viruses have been shown to generate CTLs. Although the majority of these data have been collected from in vitro studies $(12,50,51)$, a limited number of investigations suggest that similar events occur in vivo (7, 16-18, 26; A. E. Lukacher, V. L. Braciale, and T. J. Braciale, J. Exp. Med., in press). CTLs can lyse infected cells and are involved in the accompanying reduction of infectious virus. Yet our knowledge of how CTLs control virus replication is incomplete. Most studies involve the use of heterogeneous populations of primed lymphoid cells in which CTLs are but one of several lymphoid cell subsets. It is therefore uncertain whether the CTLs alone or only in concert with other lymphoid cell(s) reduce virus titers and limit virus spread. Indeed, there is evidence that CTLs seem to lyse virus-infected cells but that they do not by themselves reduce virus titer. Using depletion and reconstitution experiments, McFarland (28) identified the macrophage as the primary cell involved in reducing virus titers.

The recent availability of cloned virus-specific, major histocompatibility complex-restricted CTLs provides the opportunity for direct study of CTL-infected cell interactions. We have used cells infected with lymphocytic choriomeningitis virus (LCMV) because this virus does not lyse the cell it infects $(5,24)$, does not alter the protein synthesis of the cell $(5,24,47)$, and is a natural pathogen for the animal species used. Injury to target cells or alteration in virus titers

\footnotetext{
* Corresponding author.

† Publication no. 3575-IMM from the Department of Immunology, Scripps Clinic and Research Foundation.
}

is therefore likely to be a direct effect of the CTLs per se and not to be related to virus-induced target cell lysis accompanying the release of proteolytic enzymes.

To determine how CTLs limit virus titers, we evaluated the release and activity of such proteins as interferon and interleukin-2 (IL-2) and investigated the effect of monensin, a monovalent ionophore that blocks the appearance and release of secretory glycoproteins in eucaryotic cells (40). Finally, we analyzed the CTL-target cell interaction at the ultrastructural level.

Here we report that cloned CTLs can directly reduce virus titers, in part, with no accessory cells participating. These CTLs act effectively both during the early (before the release of infectious virus) and late (after the release of infectious virus) phases of infection. IL-2 does not participate in this response, and interferon, although synthesized, has no direct correlation with lysis of the infected cells.

\section{MATERIALS AND METHODS}

Virus. The Armstrong CA1371 strain of LCMV was used. The cloning, handling, storage, and use of this virus as well as its biochemical markers have been documented $(1,15)$. Infectious virus present in culture fluids was measured by plaque assay on Vero cells (1).

Target cell. MC-57 cells, a continuous macrophage line derived from C57BL6/J mice (H-2bb), L-929 cells derived from $\mathrm{C} 3 \mathrm{H} / \mathrm{HeJ}$ mice $(\mathrm{H}-2 \mathrm{kk})$, and $\mathrm{BALB} / \mathrm{Cl}-7$ cells derived from BALB mice ( $\mathrm{H}-2 \mathrm{dd})$ were used throughout. MC-57 cells were grown in RPMI-1640 medium, whereas L-929 and BALB/Cl-7 cells were carried in minimal essential media. All media were supplemented with 5 to $10 \%$ heat-inactivated fetal calf serum $\left(56^{\circ} \mathrm{C}\right.$ for $\left.30 \mathrm{~min}\right), 1 \%$ glutamine, penicillin, and streptomycin. Cells were infected with LCMV at a multiplicity of 0.5 to 3 . Quantitation of the $\mathrm{H}-2 \mathrm{bb}$ molecules on the surfaces of uninfected or LCMV-infected MC-57 
target cells was done with a mixture of monoclonal antibodies that recognized $\mathrm{H}-2 \mathrm{~K}^{\mathrm{b}} \mathrm{D}^{\mathrm{b}}$ molecules, and fluorescein isothiocyanate-conjugated rabbit antibody to mouse immunoglobulin (M-FITC). Infected and uninfected viable cells $(5 \times$ $10^{5}$ ) suspendêd, in $20 \mu \mathrm{l}$ of monoclonal antibody, were agitated for $30 \mathrm{~min}$ at $4^{\circ} \mathrm{C}$. After one wash, the cells were incubated with conjugated rabbit antibody for $30 \mathrm{~min}$ at $4^{\circ} \mathrm{C}$. Antibodies were added in excess to ensure saturation of antigenic sites on the cell surface. After three washes, the cells were suspended in $1 \%$ Formalin in phosphate-buffered saline and studied in a fluorescent activated cell sorter. Ten thousand cells were counted, and the mean fluorescence intensity index was calculated as dešcribed previously (14, $30)$. Briefly, the mean fluorescence intensity index may be expressed as $\Sigma n(i) x(i) / \Sigma n(i)$, where $n(i)$ is the number of cells in the $i^{n}$ channel, $x(i)$. The number of LCMV glycoproteins expressed on the surfaces of MC-57-infected and uninfected target cells during the course of infection was measured by a similar procedure, except that monoclonal antibodies réacting with both known LCMV glycoproteins, Gp1 and $\mathrm{Gpz}$, were used $(4,23)$. Monoclonal antibodies to $H-2 K^{b} D^{b}$ were obtained from the American Type Culturé Collection, Rockville, Md., and David Sachs at the National Institutes of Health, Bethesda, Md. Monoclonal antibodies to LCMV glycoproteins were obtained from Michael Buchmeier, Research Institute of Scripps Clinic, La Jolla, Calif. Use of these antibodies with fluorochrome dyes conjugated to antibody to mouse immunoglobulin $\mathrm{G}$ for fluorescence microscopy studies has been deśscribed previously (30).

CTL clones. LCMV-specific CTL clones were generated from C57BL/6 mice (H-2bb) as described previously (6). Clones obtained by the limiting dilution technique have been maintained for over 21 months. They are passaged weekly by coculturing with LCMV-infected syngeneic macrophages (treated with 2,000 rads) and syngeneic splenic cells in RPMI-1640 medium supplemented with heat-inactivated calf serum, $1 \%$ glutamine, antibiotics, $30 \%$ mouse $\mathrm{T}$ cell growth factor obtained by concanảvalin A treatment (6), designated here as IL-2, and $5 \times 10^{-5} \mathrm{M} \beta$-mercaptoethanol. Approximately every 7 days, autologous irradiated feeder spleen cells were added and clones were restimulated with irradiated LCMV-infected syngeneic macrophages (6). These clones are virus specific in that they kill LCMV-infected syngeneic targets but fail to lyse either uninfected syngeneic targets or syngeneic targets infected with pichinde virus or vaccinia virus (6). The clones are also $\mathrm{H}-2$ restricted in that they kill H-2bb LCMV-infected targets but fail to kill LCMVinfected $\mathrm{H}-2 \mathrm{dd}$ or $\mathrm{H}-2 \mathrm{kk}$ targets. These cloned CTLs bear Thy1.2 and Lyt2 molecules on their surface but do not express Lyt1 (6). In contrast, LCMV-infected syngeneic macrophages and uninfected syngeneic splenic cells both fail to lyse virus infected cells and reduce virus titers. CTL clones G4 and B10 were obtained from Michael Bevan, Research Institute of Scripps Clinic, La Jolla, Calif. The G4 clone kills targets expressing $\mathrm{D}^{\mathrm{d}}$, and the $\mathrm{B} 10$ clone lyses cells expressing $L^{d}$.

Killing by cloned CTLs and lymphocytes harvested from the spleens of C57BL/6 mice 7 to 8 days after infection with LCMV $\left(10^{5}\right.$ PFU intracerebrally or intraperitoneally) was quantitated with a ${ }^{51} \mathrm{Cr}$ release assay. Uninfected or LCMVinfected MC-57 cells were used as targets. A minimum of two ratios of effector to target cells was used, and all samples were processed in triplicate. The labeling of target cells with ${ }^{51} \mathrm{Cr}$, the conditions of the assay, and methods of calculation have been described previously (6).

To judge the effect of monensin on CTL-induced lysis, either cloned CTLs or lymphocytes obtained from the spleens of C57BL/6 mice immunized 7 to 8 days earlier with LCMV were incubated with various molar concentrations of the drug. After a 30-min incubation, CTLs were added to ${ }^{51} \mathrm{Cr}$-labeled uninfected or LCMV-infected MC-57 target cells that had previously been incubated for $10 \mathrm{~min}$ in monensin. The amount of ${ }^{51} \mathrm{Cr}$ specifically released after $5 \mathrm{~h}$ was measured. The monensin was obtained from Richard Compans, Department of Microbiology, University of Alabama Medical School, Birmingham, Ala.

Quantitation of lymphokines. Supernatant fluids obtained from either cultured target cells $\left(2 \times 10^{4}\right.$ cells per well, infected with LCMV [multiplicity of infection of 0.5 to 3]) alone, cloned CTLs ( $10^{5}$ cells per well) alone, or target cells and cloned CTLs interacted together were harvested and assayed directly or after spinning at $160,000 \times g$ to remove viral particles. After $6 \mathrm{~h}$ of incubation at $37^{\circ} \mathrm{C}$ in flat-bottom microtiter plates, supernatant fluids cleared of cells by low-speed $\left(500 \mathrm{rpm}\right.$ for $5 \mathrm{~min}$ at $\left.4^{\circ} \mathrm{C}\right)$ centrifugation were collected and frozen at $-20^{\circ} \mathrm{C}$ until assayed. The presence of interferon was measured by the ability of supernatant fluids to inhibit vesicular stomatitis virus replication in L-929 cells (25) and by blocking this antiviral effect with polyclonal antibodies to interferon $\alpha$ and $\beta$ (Lee Biomolecular, San Diego, Calif.) and monoclonal antibodies to $\gamma$ interferon (R. D. Schreiber, L. J. Hicks, A. Celada, and P. W. Gray, submitted for publication). To measure their ability to proliferate to a LCMV-specific signal, $10^{4}$ cloned CTLs were mixed with thioglycollate-elicited irradiated macrophages $\left(10^{5}\right.$ cells, 3,000 rads from a ${ }^{137} \mathrm{Cs}$ source) either LCMV infected (multiplicity of infection, $0.5,24 \mathrm{~h}$ postinfection) or uninfected. After $48 \mathrm{~h}$ of incubation at $37^{\circ} \mathrm{C}, 2 \mu \mathrm{Ci}$ of $\left[{ }^{3} \mathrm{H}\right]$ thymidine was added to each well, and the cells were assayed for trichloroacetic acid-precipitable counts $18 \mathrm{~h}$ later. IL-2 was measured by its ability to cause proliferation of IL-2-dependent cells (45). Briefly, supernatants (as described above, but without the $\left[{ }^{3} \mathrm{H}\right]$ thymidine addition) collected 24 and 48 h after initiating LCMV infection were assayed for the ability to proliferate IL-2-dependent CTL L-2 cells.

Electron microscopy. MC-57 cells infected for $48 \mathrm{~h}$ with LCMV were mixed with CTL clone $11-5$ at an effector/ target ratio of 5:1. CTL-target pellets were obtained by gentle centrifugation for $5 \mathrm{~min}$ at $200 \times \mathrm{g}$. After incubation for 5 to $120 \mathrm{~min}$ at $37^{\circ} \mathrm{C}$ or for $90 \mathrm{~min}$ at $20^{\circ} \mathrm{C}$ followed by 30 $\mathrm{s}$ to $5 \mathrm{~min}$ at $37^{\circ} \mathrm{C}, 1 \mathrm{ml}$ of $3 \%$ glutaraldehyde in $0.1 \mathrm{M}$ cacodylate buffer ( $\mathrm{pH} 7.3$ ) containing $5 \%$ sucrose was added to fix the cells. Fixed CTL-target pellets were washed in cacodylate buffer, treated with $1 \%$ osmium tetroxide, stained with $2 \%$ uranyl acetate, dehydrated, embedded in araldite resin, sectioned, stained with Reynold lead citrate, and observed by electron microscopy.

\section{RESULTS}

MC-57 cells as targets: expression of LCMV and major histocompatibility complex antigens and production of infectious virus and interferon. Initially, we recorded several aspects of responses by MC-57 cells during the 4-day development of LCMV infection. First, we used monoclonal antibodies to mark the major histocompatibility complex determinants, $\mathrm{H}-2 \mathrm{~K}^{\mathrm{b}} \mathrm{D}^{\mathrm{b}}$, whose recognition is required by CTLs for target lysis. The mean fluorescence intensity index of $\mathrm{H}-2 \mathrm{~K}^{\mathrm{b}} \mathrm{D}^{\mathrm{b}}$ determinants, i.e., the relative number of $\mathrm{H}-2$ molecules expressed on the surfaces of the cells (30) (Fig. 1; Table 1), did not significantly change during the 4 days of LCMV infection and (Table 1) was not significantly different from values on uninfected cells. These data complement previous reports that LCMV infection does not alter host 


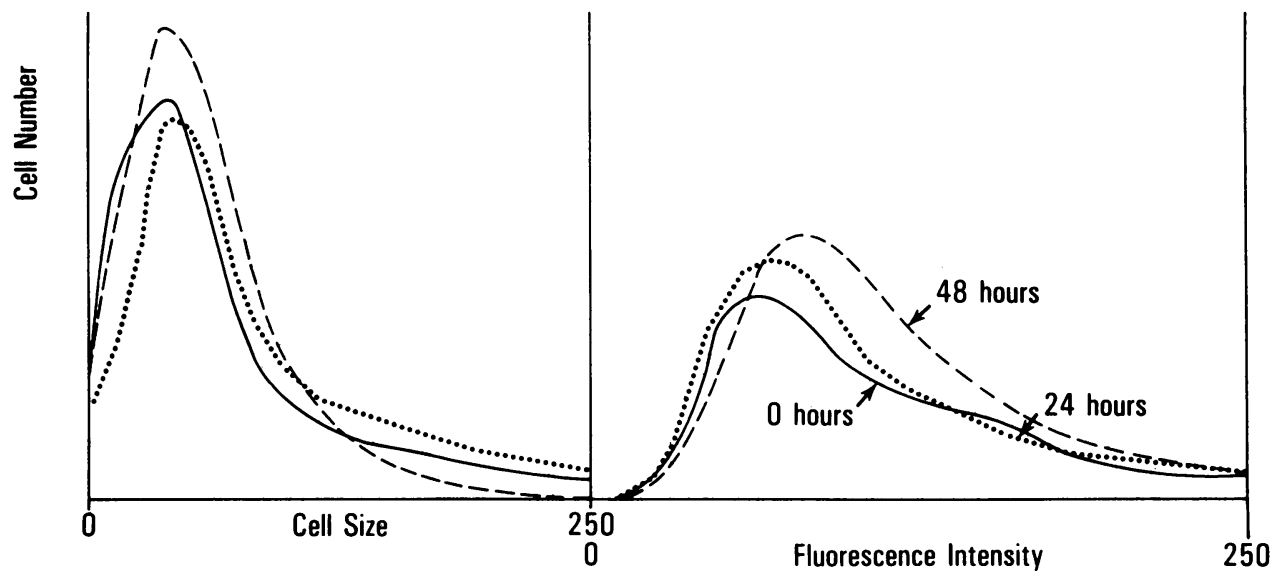

FIG. 1. Relative concentrations of $H-2 K^{b} D^{b}$ molecules expressed on the MC-57 cell surface during the first 2 days of LCMV infection. The relative concentrations of MHC determinants remained unchanged; these values were similar 3 and 4 days after infection. Results were equivalent in three other experiments.

protein synthesis $(5,24,47)$. Furthermore, our results (Table 1) suggest that production of major histocompatibility complex-modulating molecules, like interferon $(3,44)$, is unlikely during LCMV infection of MC-57 cells. Similar stability of MHC $K^{k} D^{k}$ and $K^{d} D^{d}$ gene products during LCMV infection of L-929 and BALB/Cl-7 cells was observed (data not shown). In contrast to the stable representation of $\mathrm{H}-2 \mathrm{KD}$ molecules on the surfaces of infected cells, the expression of LCMV glycoproteins varied from an early increase to a peak at 24 to $48 \mathrm{~h}$ after initiation of infection and to a decline thereafter. This restricted expression of LCMV glycoprotein occurred while the expression of LCMV nucleoprotein in the cytoplasms remained steady and is documented for MC-57 cells in Table 1. High levels of infectious LCMV was detected in culture fluids $24 \mathrm{~h}$ or more after initiation of infection.

Cloned CTLs inhibit production of infectious virus. On the basis of the foregoing result, we next tested the ability of CTL clones to inhibit the expected production of LCMV from MC-57 cells. Cloned CTLs ( $>98 \%$ Lyt $2^{+}$, Thy $1.2^{+}$) were added to $2 \times 10^{4} \mathrm{MC}-57$ cells labeled with ${ }^{51} \mathrm{Cr}$ at 30 min, $6.5 \mathrm{~h}$, and $12.5 \mathrm{~h}$ after initiation of LCMV infection. When LCMV-specific $\mathrm{H}-2$ restricted CTLs were absent,
MC -57 cells made $5 \times 10^{5}$ to $1 \times 10^{6} \mathrm{PFU}$ of virus per $\mathrm{ml}$ by $24 \mathrm{~h}$ (Fig. 2). In contrast, when cloned CTLs were present, no infectious virus was released into culture fluid. The lack of infectious virus correlated with the lysis of infected MC-57 cells. All of the several CTL clones tested that were LCMV specific and major histocompatibility complex restricted (6) were equally efficient in preventing the production of LCMV, and these CTLs inhibited virus release even when added $12.5 \mathrm{~h}$ after the initiation of infection (Fig. 2).

Subsequently, we determined the effect of cloned CTLs on infected targets actively producing infectious virus. MC-57 target cells infected with LCMV for 24 or $48 \mathrm{~h}$ and releasing infectious virus into culture fluids were labeled with ${ }^{51} \mathrm{Cr}$ and mixed with cloned CTLs. CTLs lysed these cells, and titers of infectious virus declined $12 \mathrm{~h}$ after their addition and continued to decrease during the next $12 \mathrm{~h}$ of observation (Fig. 3).

Monensin distinguishes CTL activity of clones from that of splenic lymphocytes. Additional experiments included splenic lymphocytes from uninfected C57BL/6 mice and such mice injected with LCMV 6 to 7 days earlier. Although splenocytes from infection-free mice did not affect virus titers or lyse virus-infected cells, splenic lymphoid cells from

TABLE 1. Expression of LCMV and H-2 molecules, interferon, and infectious virus by MC-57 cells during the course of infection ${ }^{a}$

\begin{tabular}{|c|c|c|c|c|c|c|}
\hline \multirow{2}{*}{$\begin{array}{l}\text { Time after } \\
\text { infection (h) }\end{array}$} & \multicolumn{2}{|c|}{$\begin{array}{l}\text { Expression of LCMV anti- } \\
\text { gens }{ }^{b}(\%) \text { on: }\end{array}$} & \multicolumn{2}{|c|}{ MFII cell surface amt. } & \multicolumn{2}{|c|}{ Expression in supernatant fluid of ${ }^{d}$ : } \\
\hline & $\begin{array}{l}\text { Cell } \\
\text { surface }\end{array}$ & Cyto & LCMV & $\mathrm{H}-2$ & $\begin{array}{l}\text { (PFU) } \\
\text { LCMV }\end{array}$ & IFN (IU) \\
\hline 0 & Nil & Nil & Nil & 46 & Nil & $<2$ \\
\hline 4 & Nil & Nil & $\mathrm{ND}^{e}$ & ND & $<10^{2}$ & ND \\
\hline 8 & Nil & Nil & ND & ND & ND & ND \\
\hline 12 & 10 & 30 & ND & ND & $<10^{2}$ & ND \\
\hline 24 & 90 & $>95$ & 57 & 51 & $4 \times 10^{5}$ & $<2$ \\
\hline 48 & 71 & $>95$ & 42 & 49 & $1 \times 10^{6}$ & $<2$ \\
\hline 72 & 30 & $>95$ & 10 & 44 & $1 \times 10^{6}$ & ND \\
\hline 96 & 10 & $>95$ & 8 & 48 & ND & ND \\
\hline
\end{tabular}

${ }^{a}$ MC-57 cells were infected (multiplicity of infection, 3) with LCMV Armstrong CA1371 strain.

${ }^{b}$ Percentage of MC-57 cells expressing LCMV antigens on their surface (cell surface) or in their cytoplasm (cyto). Two hundred cells were counted in each period. Analysis was by fluorescence microscopy.

"Mean fluorescence intensity index (MFII) calculated from counting, in the fluorescent activated cell sorter, $10^{5}$ infected cells labeled with fluoresceinconjugated antibodies recognizing either LCMV glycoproteins or $\mathrm{H}-2 \mathrm{~K}^{b} \mathrm{D}^{b}$ molecules.

${ }^{d}$ PFU as determined on Vero cells. Interferon (IFN) titer expressed in international units. Level of detection, $>2 \mathrm{U}$.

e ND, Not determined. 
0 Hrs. Post-infection

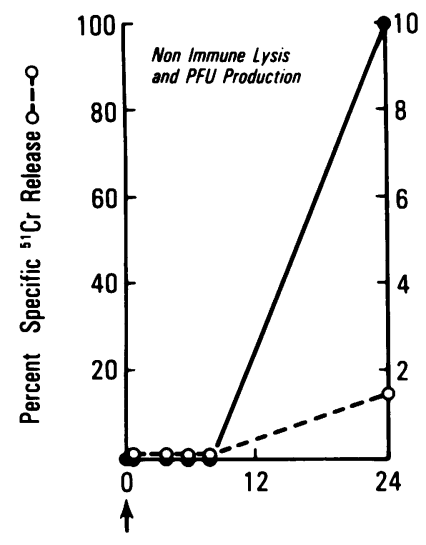

12 Hrs. Post-infection

6 Hrs. Post-infection

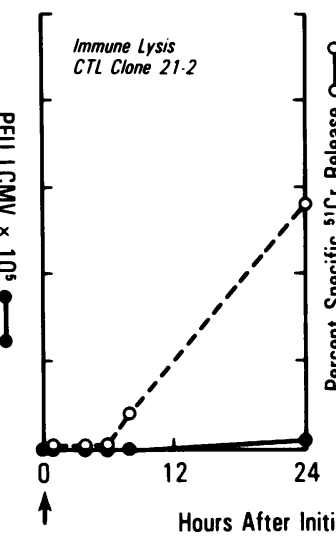$$
\text { 西 }
$$

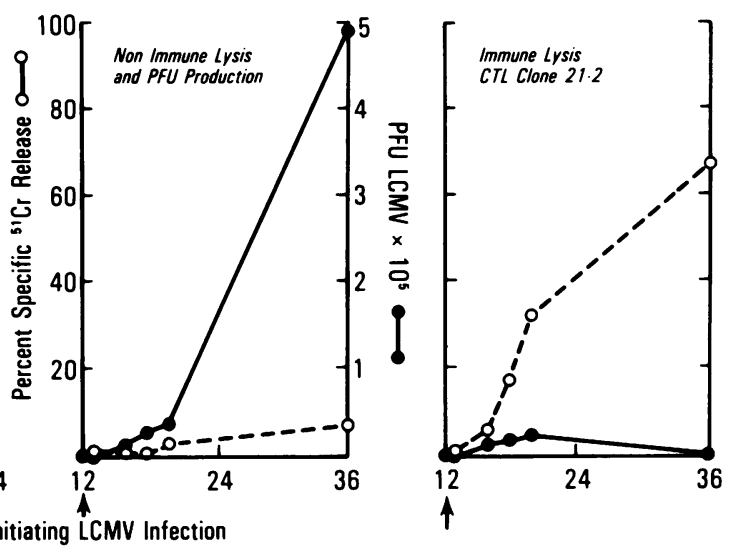

12 Hrs. Post-infection
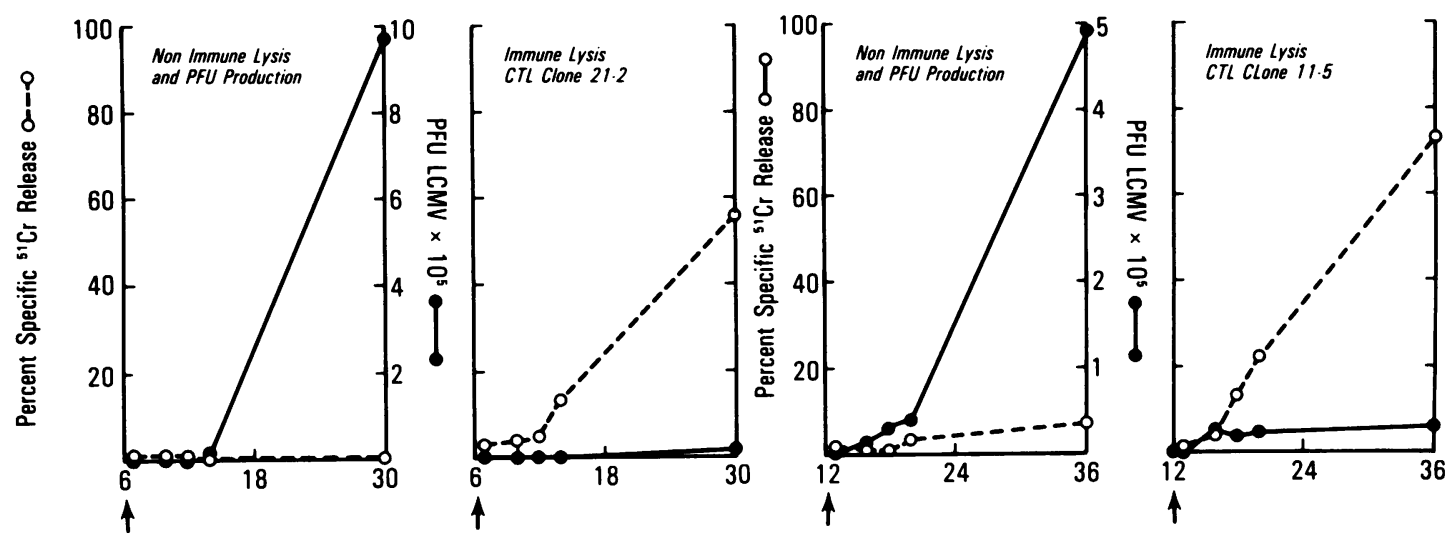

Hours After Initiating LCMV Infection

FIG. 2. LCMV-specific, H-2-restricted CTL clones lysed virus-infected cells before production of virus and prevented the release of virus into culture fluids. The CTL effector/MC-57 ratio was $2.5: 1$. Specific ${ }^{51} \mathrm{Cr}$ release $(O)$ was measured over 4 -h periods. Each point represents the mean of triplicate samples. The variance was less than $10 \%$. Infectious virus ( $)$ was measured as PFU on Vero cells.

infected mice were effective in lysing MC-57 LCMV-infected cells and lowering virus titers (data not shown). Others have shown that the effect is dependent on virus-specific, $\mathrm{H}-2$ restricted T cells $(6,8,9,12,27,49)$. We tested monensin, an ionophore that blocks the appearance of membrane glycoproteins on the cell surface and the release of secretory glycoproteins from the Golgi complex (39-42) on CTL lysis. Monensin inhibited CTL-directed, virus-specific $\mathrm{H}$-2 lysis by primed splenic lymphocytes over a wide dose range (Fig. 4). In contrast, over the same molar dose range, monensin failed to inhibit the lysis of MC-57 LCMV-infected cells by the cloned CTLs.

CTL clones release interferon but not IL-2. We next determined the ability of LCMV-specific, H-2b-restricted CTL clones to proliferate when exposed to LCMV antigens in the context of $\mathrm{H}-2 \mathrm{~b}$ molecules and to release IL- 2 . If CTLs did release IL-2, they could supply their own help and thereby increase their own survival, since they are IL-2 dependent $(2,6,31)$, as well as activate other CTLs in the locality. Cloned CTLs proliferated when reacted with LCMV-infected macrophages from $\mathrm{H}-2 \mathrm{~b}$ mice (Table 2). Nevertheless, there was no detectable release of IL-2. Cloned CTLs did not proliferate when cocultured with uninfected $\mathrm{H}-2 \mathrm{~b}$ macrophages (Table 2).
Analysis of the relationship between interferon release by cloned CTLs and their ability to lyse virus infected targets showed that interferon was made only by CTL clones reacted with the appropriate virus-infected and $\mathrm{H}$-2-restricted target (Table 2). Thus, BALB/Cl-7 cells ( $\mathrm{H}-2 \mathrm{~d}$ ) infected with LCMV failed to induce interferon release from LCMV-specific, H-2b-restricted CTLs. Although interferon was made when CTLs were cocultured with an infected syngeneic target, there was no firm correlation between interferon release and CTL killing. CTL clone 9.3 that had lost its lytic ability still released interferon (Table 2). Furthermore, CTL clone 21.3 released fourfold less interferon than clone 11.13 under the same conditions but was a more effective killer. By using polyclonal antibodies against $\alpha$ and $\beta$ interferon and monoclonal antibody to $\gamma$ interferon, we showed that the interferon made by CTL clones was $\gamma$ interferon. Table 2 indicates that the antiviral activity of the interferon released from CTL clones 11.13 and 21.2 could be completely blocked by incubation with monoclonal antibodies to interferon $\gamma$. In contrast, similar treatment with antibody to $\alpha$ or $\beta$ interferon did not block the vesicular stomatitis virus plaque reductions by interferon in the supernatant.

CTL clone-target cell interaction as visualized by electron microscopy. CTL clones were readily differentiated from 


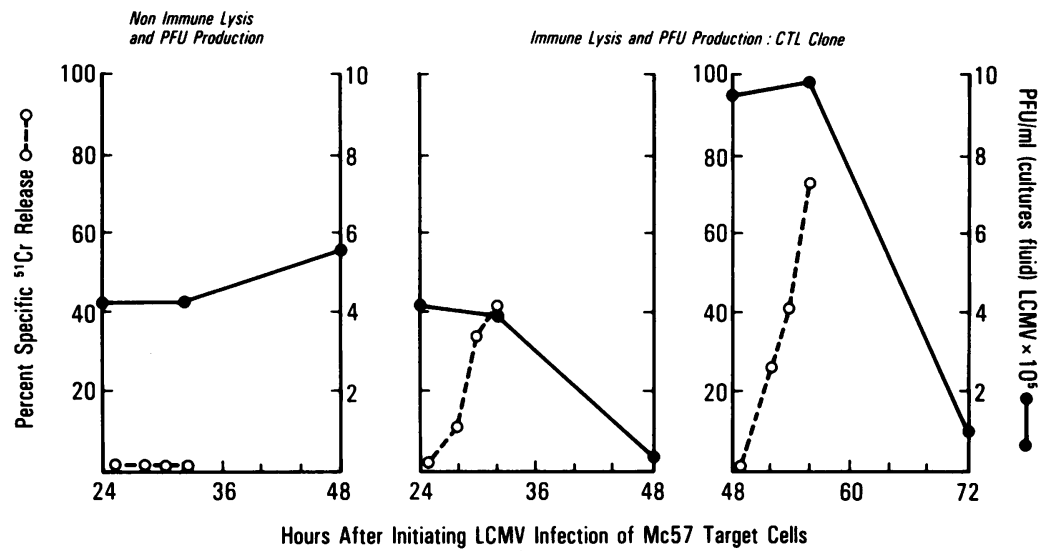

FIG. 3. LCMV-specific, H-2-restricted CTLs lysed virus-infected cells in the process of producing infectious virus and reduced the amount of virus in culture fluids. CTL effector/MC-57 target ratio was 2.5:1. Specific ${ }^{51} \mathrm{Cr}$ release $(\mathrm{O})$ was measured over 4-h periods. Each point represents the mean of triplicate samples. The variance was less than $10 \%$. Infectious virus (O) was measured as PFU on Vero cells.

infected MC-57 target cells, owing to the numerous cytoplasmic inclusions in the CTL clones (Fig. 5a, b). These membrane-bound structures were 1 to $2 \mu \mathrm{m}$ in diameter and contained electron-dense granules, multilamellar membrane figures, and occasionally unilamellar membrane structures (Fig. 5b). Over a spectrum of incubation times and procedures, a morphological picture emerged in which plasma membranes of the CTLs and target cells were in close opposition, frequently with CTLs pushing fingerlike protrusions into the target cells. On occasion, such protrusions came close to the nuclear membrane (Fig. 5a). Thin-section electron microscopy showed no evidence of structural alterations in plasma membranes of either the CTLs or target cells in areas of contact.

To examine the membranes of MC-57 cells lysed by cloned CTLs, effectors and targets were incubated at a ratio of $1: 1$. After $16 \mathrm{~h}$, the mixture was centrifuged for $5 \mathrm{~min}$ at $1,000 \times g$, and the supernatant was removed and centrifuged for $30 \mathrm{~min}$ at $25,000 \mathrm{rpm}$ in a Beckman SW-41 rotor. The resulting membrane pellet was suspended in phosphate-buffered saline containing $100 \mu \mathrm{g}$ of trypsin per $\mathrm{ml}$ and incubated for $16 \mathrm{~h}$ at $20^{\circ} \mathrm{C}$. The membranes were repelleted and examined after negative staining in $2 \%$ phosphotungstic acid with the $\mathrm{pH}$ adjusted to 6.5. Examination of such membranes revealed lesions with internal and external diameters of $14.5 \pm 2.5$ and $23.0 \pm 2.5 \mathrm{~nm}$, respectively (Fig. 5c).

\section{DISCUSSION}

By using cloned CTLs we found that these cells alone, in the absence of any accessory cells, can prevent the production and release of infectious virus. Previous investigators used heterogeneous donor lymphoid populations and frequently viruses that abortively or lytically infected cells $(12$, 28, 49-51). Therefore, neither the precise identity of the effector cell nor how its activity occurred could be fully ascertained. The antiviral mechanism involved is efficient and occurs presumably by the attack and destruction of infected cells acting as factories for the manufacture of virus (48). Furthermore, as cells are lysed they release a variety of proteolytic enzymes and factors that can reduce the amount of infectious virus present in supernatant fluids. Electron microscopic analysis of the CTL-target cell interaction shows that a major manifestation was the insertion of fingerlike protrusions from the CTL into the target cell and the donut-type lesion on the membrane of the target cell. Plasma membrane at the site of the CTL-target interaction showed
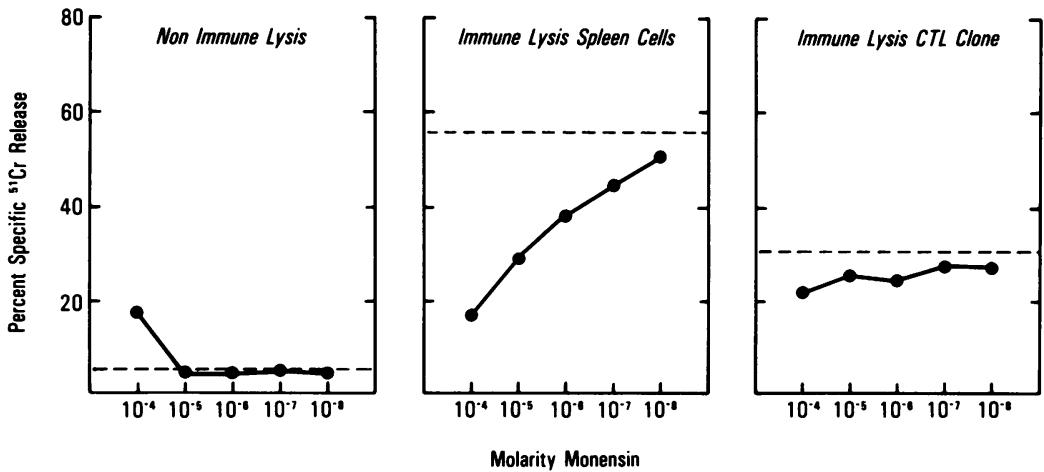

FIG. 4. Monensin inhibits a heterogeneous population of primed lymphoid cells (containing CTL effectors) from lysing LCMV-infected MC-57 cells but has no effect on LCMV-specific, H-2-restricted cloned CTLs. Splenic lymphoid cells were harvested 7 to 8 days after inoculation of C57BL/6 mice with LCMV $\left(10^{5} \mathrm{PFU}\right.$ intraperitoneally) and used at effector-to-target ratios of 50:1 (shown) and 20:1 (not shown). Cloned CTLs were used at an effector-to-target cell ratio of 2.5:1, with MC-57 target cells. MC-57 cells were labeled with ${ }^{51} \mathrm{Cr}$ and incubated with the concentrations of monensin shown. After $10 \mathrm{~min}$, targets were mixed with a CTL source that had been previously incubated with monensin for $30 \mathrm{~min} .{ }^{51} \mathrm{Cr}$ release was measured $5 \mathrm{~h}$ later. Dashed lines in all panels record ${ }^{51} \mathrm{Cr}$ release by various $\mathrm{CTL}$ populations in the absence of monensin. 
TABLE 2. Proliferation and IL-2 and interferon production of LCMV-specific H-2-restricted CTL clones

\begin{tabular}{|c|c|c|c|c|c|c|c|c|c|c|c|}
\hline \multirow{3}{*}{$\begin{array}{l}\text { CTL } \\
\text { clone } \\
\text { (H-2b) }\end{array}$} & \multicolumn{2}{|c|}{ Proliferation $(\mathrm{cpm})^{a}$ of: } & \multicolumn{2}{|c|}{ IL-2 production ${ }^{b}$ of: } & \multicolumn{3}{|c|}{ CTL lysis for ${ }^{c}:$} & \multicolumn{3}{|c|}{ IFN release (IU) } & \multirow{3}{*}{$\gamma \mathrm{IFN}^{d}$} \\
\hline & \multirow{2}{*}{$\begin{array}{l}\mathrm{H}-2 \mathrm{~b} \\
\text { MAC }\end{array}$} & \multirow{2}{*}{$\begin{array}{c}\mathrm{H}-2 \mathrm{~b} \\
\mathrm{MAC} / \mathrm{LCMV}\end{array}$} & \multirow{2}{*}{$\begin{array}{l}\mathrm{H}-2 \mathrm{~b} \\
\text { MAC }\end{array}$} & \multirow{2}{*}{$\begin{array}{c}\text { H-2b } \\
\text { MAC:LCMV }\end{array}$} & \multicolumn{2}{|c|}{ H-2b/LCMV at } & \multirow{2}{*}{$\begin{array}{c}\mathrm{H}-2 \mathrm{~b} \\
\text { (unin- } \\
\text { fected) } \\
\text { at } 5: 1\end{array}$} & \multirow{2}{*}{$\begin{array}{l}\text { H-2b/ } \\
\text { LCMV }\end{array}$} & \multirow{2}{*}{$\begin{array}{c}\mathrm{H}-2 \mathrm{~b} \\
\text { (unin- } \\
\text { fected) }\end{array}$} & \multirow{2}{*}{$\begin{array}{l}\mathrm{H}-2 \mathrm{~d} / \\
\mathrm{LCMV}\end{array}$} & \\
\hline & & & & & $5: 1$ & $1: 1$ & & & & & \\
\hline 9.1 & 2,708 & 17,037 & Nil & Nil & ND & ND & ND & ND & ND & ND & ND \\
\hline 9.3 & 2,645 & 4,322 & Nil & Nil & 2 & Nil & Nil & 13 & Nil & Nil & ND \\
\hline 11.2 & 2,475 & 5,446 & Nil & Nil & ND & ND & ND & ND & ND & ND & ND \\
\hline 11.5 & 1,833 & 25,154 & Nil & Nil & ND & ND & ND & ND & ND & ND & ND \\
\hline 11.13 & 929 & 16,310 & Nil & Nil & 28 & 13 & Nil & 211 & Nil & Nil & +++ \\
\hline 19.7 & 3,728 & 53,415 & Nil & Nil & ND & ND & ND & ND & ND & ND & ND \\
\hline 21.2 & 1,487 & 32,449 & Nil & Nil & 37 & 13 & Nil & 53 & 6 & 6 & +++ \\
\hline 21.3 & ND & ND & ND & ND & 46 & 15 & Nil & 53 & Nil & Nil & ND \\
\hline
\end{tabular}

${ }^{a}$ Thioglycollate-induced peritoneal macrophages (MAC) $\left(10^{5}\right)$ were infected with LCMV (multiplicity of infection, 2 ), irradiated, and mixed with $10^{4}$ cloned CTLs. After $48 \mathrm{~h}$ of incubation, $2 \mu \mathrm{Ci}$ of $\left.{ }^{3} \mathrm{H}\right]$ thymidine was added per well, and trichloroacetic acid-precipitable counts were determined $18 \mathrm{~h}$ later. Data represent the mean of triplicate samples assayed. Variance was usually $<10 \%$ within a group. In the absence of added CTLs, proliferation of uninfected and infected macrophages was 1,080 and $1,757 \mathrm{cpm}$, respectively.

${ }^{b}$ IL-2 production was assayed on IL-2-dependent CTLs as described previously $(6,45)$. No IL-2 was found in culture fluids after 24 or 48 h of active CTL proliferation in the presence of LCMV-infected, H-2-restricted, thioglycollate-elicited peritoneal macrophages.

c All samples were run in triplicate. CTL lysis was measured as percent specific ${ }^{51} \mathrm{Cr}$ release. Interferon (IFN) released in the culture fluids during the CTL assay was measured by its ability to inhibit vesicular stomatitis virus replication in L-929 cells. Interferon data are given in international units. Positive and negative controls were run concurrently.

${ }^{d} \gamma$ Interferon (IFN) was detected with monoclonal antibody, which totally removed the interferon activity. In contrast, polyclonal antibodies to interferon $\alpha$ and $\beta$ had no effect on inhibition of vesicular stomatitis virus plaques.

e ND, Not done.

minimal alterations. The lesions present on membranes from lysed cells showed internal diameters of approximately 15 $\mathrm{nm}$. These lesions appeared similar in size and morphology to those described by Dourmashkin et al. (13) in antibody-dependent cellular cytotoxicity and by Dennert and Podack (11) in natural killer cell and allogeneic T-cell killing. In other studies, we developed several monoclonal antibodies that specifically inhibited LCMV-specific, H-2-restricted CTL lysis. When used in vitro, these antibodies check the ability of CTLs to curtail virus production, again suggesting the direct role of CTLs in modulating infectious virus titer.

These cloned CTLs limit virus production and destroy virus-infected cells even in the presence of monensin. Monensin is believed to inhibit the exit of membrane glycoproteins from the Golgi complex (39-42), blocking their appearance on the cell surface and their release. Apparently, lysis by committed cloned CTLs does not require newly processed glycoproteins. If such glycoproteins are involved in the lytic event, they may already be present in the membrane or at cytoplasmic sites in membrane-bound inclusions. In contrast, CTLs from the spleens of infected animals are susceptible to the effects of monensin. Thus, these experiments indicate a useful way to segregate the activity of these two CTL populations and suggest that cloned CTLs may be at a later stage of differentiation than primed splenic CTLs. Furthermore, they imply the need for some caution in interpreting effects caused by different populations of CTLs. For example, CTL activity measured from primed splenic cells probably requires the participation and interdependence of several cell types, including IL-2-producing $T$ helper cells (2). Others using uncloned cell populations in in vivo experiments with LCMV infection have reported that Lyt $2 \mathrm{~T}$ cells are not by themselves cytotoxic and that there is a poor correlation between lysis of virus-infected cells by CTLs and clearance of virus $(33,43)$. In contrast to these reports, we show here that cloned CTLs bearing Lyt2 markers lyse virus-infected cells and clear virus in vitro, and
Byrne and Oldstone reported a similar function for these cloned CTLs in vivo (7).

Lytic activity by LCMV specific $\mathrm{H}-2$ restricted CTL clones appears not to correlate directly with interferon production. We find no direct parallel between the strength of their lytic activity and the magnitude of their interferon production. For example, a CTL clone that lost its ability to kill nevertheless continued to make interferon. Helper $\mathrm{T}$ lymphocytes can also release $\gamma$ interferon but do not lyse virus-infected target cells (19). Others have reported a role for interferon in lysis by LCMV CTLs $(21,32)$. However, such studies used neither cloned CTLs as effectors nor monoclonal antibodies to block interferon activity and contributions by additional populations of lymphoid cells or activities of other lymphokines. Nevertheless, the release of $\gamma$ interferon by CTLs in vivo could have an antiviral effect. Recent studies indicate that interferon can regulate immune responses $(10,34)$, for example, by the maturation of $B$ (antibody-producing) lymphocytes (36), activating macrophages (38), or other types of cytotoxic (natural killer) lymphocytes (46) or all three. The availability of LCMV CTL clone 9.3 that does not lyse virus-infected cells but does release $\gamma$ interferon and of monoclonal antibody to $\gamma$ interferon provides valuable reagents for testing the antiviral role of $\gamma$ interferon in vivo.

As expected, the production of interferon and the proliferation of cloned CTLs was virus specific. Similar findings have been reported by Morris et al. for cloned CTLs against influenza virus (29) and by Klein et al. for cloned CTLs reactive with nonviral antigen or mitogen (22). However, we were somewhat surprised that LCMV CTL clones which are IL-2 dependent (6) did not produce IL-2, especially since these clones were active in vivo in reducing the logarithm of the LCMV infectious titer by 3 to 4 during a 4-day period (7) and migrated throughout a 48-h observation time (J. Byrne and M. B. A. Oldstone, submitted for publication). Thus, either these cloned CTLs injected in vivo may be supplied with IL-2 at local sites or the factors they release may 

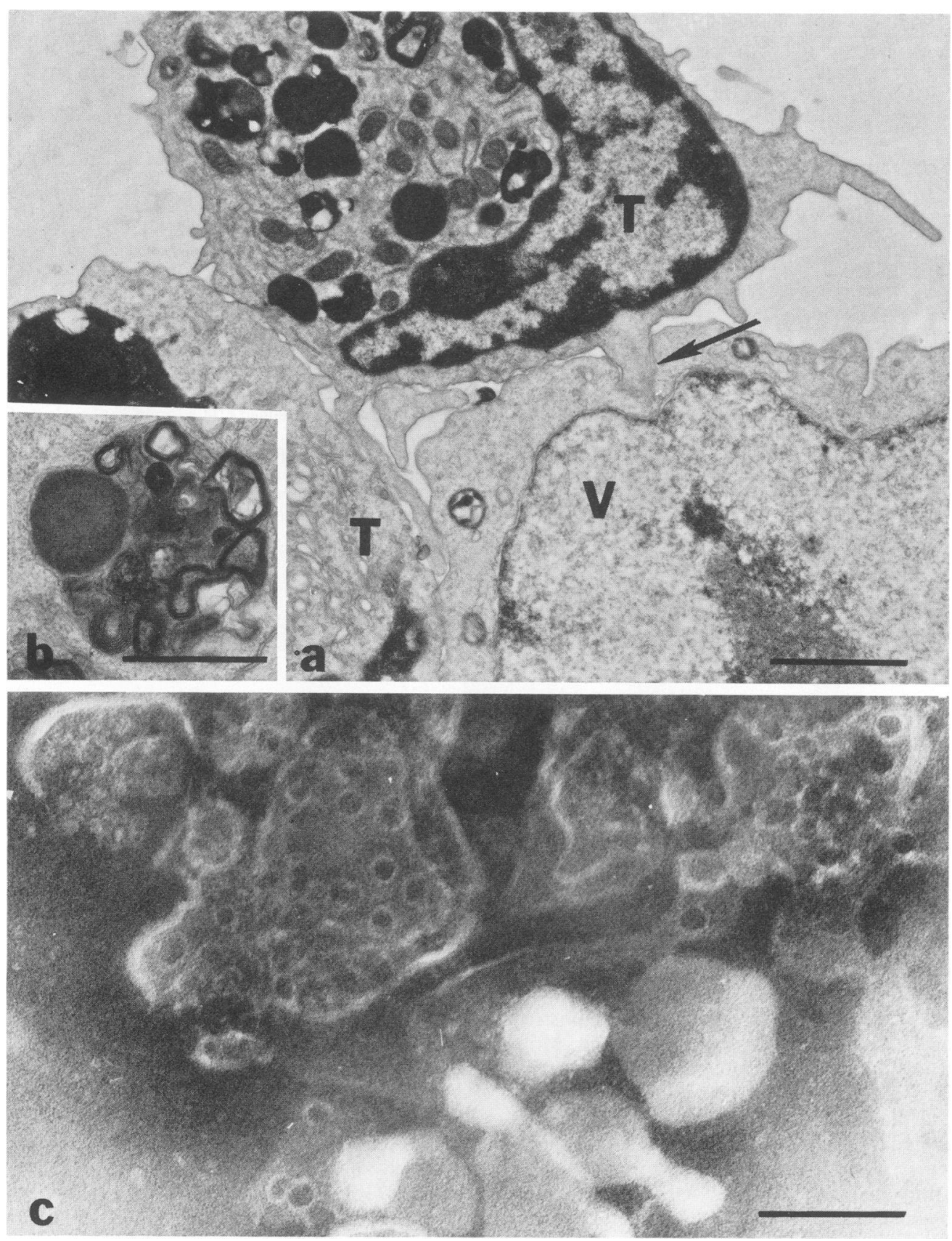

FIG. 5. Interaction between cloned CTLs and LCMV-infected MC-57 cells. a, Two CTLs (T) bound to an LCMV-infected MC-57 cell (V). A penetrating CTL process (arrow) almost reaches the nuclear membrane of the target cell. The bar represents $2 \mu \mathrm{m}$. b, CTL membrane-bound cytoplasmic inclusion containing an electron dense granule and multilamellar membrane structures. The bar represents 1 $\mu \mathrm{m}$. c, Lesions on the membrane of a cell lysed by CTLs. The bar represents $100 \mu \mathrm{m}$.

activate other effective antiviral reactants. Other investigators (35) noted that CTL clones produced IL-2 in vitro upon specific antigen presentation. Our clones were tested for IL-2 production after several months in culture and perhaps lost their IL-2-producing ability at this later time.

Finally, the availability of cloned CTLs that are virus specific and $\mathrm{H}-2$ restricted in concert with genes coding for the viral (37) and H-2 glycoproteins (20) and antibody to the CTL receptor (J. Anderson and M. B. A. Oldstone, unpublished observations) should provide materials for study of the three-dimensional structure of the CTL receptor and its restricting elements.

\section{ACKNOWLEDGMENTS}

This work was supported in part by Public Health Service grants no. AI-09484 (to M.B.A.O., J.A., and J.B.) and CA-34120 (to R.S.) and Biomedical Research Support grant no. RRO-5514 from the National Institutes of Health and a grant to R.S. from Eli Lilly Research Laboratories. J.B. is supported by Public Health Service training grant no. NS-07078. S.P. is the recipient of a fellowship from 
the United Kingdom Medical Research Council and is supported in part by grant no. NS-12428.

We thank Michael Bevan and Richard Compans for critical discussion and Gay Wilkins and Sally Booz for manuscript preparation.

\section{LITERATURE CITED}

1. Ahmed, R., A. Salmi, L. D. Butler, J. M. Chiller, and M. B. A. Oldstone. 1984. Selection of genetic variants of lymphocytic choriomeningitis virus in spleens of persistently infected mice: role in suppression of cytotoxic $\mathrm{T}$ lymphocyte response and viral persistence. J. Exp. Med. 60:521-540.

2. Andrus, L., A. Granelli-Piperno, and E. Reich. 1984. Cytotoxic $\mathrm{T}$ cells both produce and respond to interleukin 2. J. Exp. Med. 59:647-652.

3. Basham, T., and T. C. Merigan. 1982. Immunoregulation by gamma-interferon. Nature (London) 299:778-780.

4. Buchmeier, M. J., H. A. Lewicki, O. Tomori, and M. B. A. Oldstone. 1981. Monoclonal antibodies to lymphocytic choriomeningitis viruses: generation, characterization and cross-reactivity with other areanviruses. Virology 113:73-85.

5. Buchmeier, M. J., R. M. Welsh, F. J. Dutko, and M. B. A. Oldstone. 1980. The virology and immunobiology of lymphocytic choriomeningitis virus infection. Adv. Immunol. 30: 275-331.

6. Byrne, J. A., R. Ahmed, and M. B. A. Oldstone. 1984. Biology of cloned cytotoxic $\mathrm{T}$ lymphocytes specific for lymphocytic choriomeningitis virus. I. Generation and recognition of virus strains and $\mathrm{H}-2^{\mathrm{b}}$ mutants. J. Immunol. 133:433-439.

7. Byrne, J. A., and M. B. A. Oldstone. 1984. Biology of cloned cytotoxic $\mathrm{T}$ lymphocytes specific for lymphocytic choriomeningitis virus: clearance of virus in vivo. J. Virol. 51:682-686.

8. Cole, G. A., N. Nathanson, and R. A. Pendergast. 1972. Requirements for $\theta$ bearing cells: lymphocytic choriomeningitis virus induced central nervous system disease. Nature (London) 238:335-337.

9. Cole, G. A., R. A. Pendergast, and C. S. Henney. 1973. In vitro correlates of LCMV virus-induced immune response, p. 61-71. In F. Lehmann-Grube (ed.), Lymphocytic choriomeningitis virus and other arenaviruses. Springer-Verlag KG, Berlin.

10. DeMaeyer, E., and J. DeMaeyer-Guignard. 1981. Interferons as regulatory agents of the immune system. Crit. Rev. Immunol. 2:167-172.

11. Dennert, G., and E. R. Podack. 1983. Cytolysis by H-2-specific T killer cells. J. Exp. Med. 157:1483-1495.

12. Doherty, P. C., and R. M. Zinkernagel. 1974. T cell mediated immunopathology in viral infections. Transplant. Rev. 19: 89-120.

13. Dourmashkin, R. R., P. Deteix, C. B. Simone, and P. Henkart. 1980. Electron microscopic demonstration of lesions in target cell membranes associated with antibody-dependent cellular cytotoxicity. Clin. Exp. Immunol. 42:554-560.

14. Durand, R. E. 1981. Calibration of flow cytometry detector systems. Cytometry 2:192-193.

15. Dutko, F. J., and M. B. A. Oldstone. 1983. Genomic and biological variation among commonly used lymphocytic choriomeningitis virus strains. J. Gen. Virol. 64:1689-1698.

16. Gilden, D. H., G. A. Cole, A. A. Monjan, and N. Nathanson. 1972. Immunopathogenesis of acute central nervous system disease produced by lymphocytic choriomeningitis virus. I. Cyclophosphamide mediated induction of virus-carrier state in adult mice. J. Exp. Med. 135:860-873.

17. Gilden, D. H., G. A. Cole, and N. Nathanson. 1972. Immunopathogenesis virus. II. Adoptive immunization of virus carriers. J. Exp. Med. 135:874-889.

18. Griffin, D. E. 1984. The inflammatory response to acute viral infections, p. 46-52. In A. L. Notkins and M. B. A. Oldstone (ed.), Concepts in viral pathogenesis. Springer-Verlag, New York.

19. Hecht, T. T., D. L. Longo, and L. A. Matis. 1983. The relationship between immune interferon production and proliferation in antigen-specific, MHC-restricted $\mathrm{T}$ cell lines and clones. J.
Immunol. 131:1049-1055.

20. Hood, L., M. Steinmetz, and R. Goodenow. 1982. Genes of the major histocompatibility complex. Cell 28:685-687.

21. Jacobson, S., R. M. Friedman, and C. J. Pfau. 1981. Interferon induction by lymphocytic choriomeningitis viruses correlates with maximum virulence. J. Gen. Virol. 57:275-283.

22. Klein, J. R., D. H. Raulet, M. S. Pasternack, and M. J. Bevan. 1982. Cytotoxic $T$ lymphocytes produce immune interferon in response to antigen or mitogen. J. Exp. Med. 155:1198-1203.

23. Kohler, G., and C. Milstein. 1975. Continuous cultures of fused cells secreting antibody of predefined specificity. Nature (London) 256:495-497.

24. Lehmann-Grube, F., L. M. Peralta, M. Bruns, and J. Luhler. 1980. Persistent infection of mice with the lymphocytic choriomeningitis virus, p. 43-103. In H. Fraenkel-Conrat and R. Wagner (ed.), Comprehensive virology. Plenum Publishing Corp., New York.

25. Lennette, E. H., and N. J. Schmidt. 1979. Diagnostic procedures for viral rickettsial and chlamydial infections. American Public Health Association, Washington, D.C.

26. Lin, Y. L., and B. A. Askonas. 1981. Biological properties of an influenza A virus-specific killer T cell clone: inhibition of virus replication in vivo and induction of delayed-type hypersensitivity reactions. J. Exp. Med. 154:225-234.

27. Marker, O., and M. Volkert. 1973. Studies on cell-mediated immunity to lymphocytic choriomeningitis virus in mice. J. Exp. Med. 137:1511-1525.

28. McFarland, H. F. 1974. In vitro studies of cell-mediated immunity in an acute viral infection. J. Immunol. 113:173-180.

29. Morris, A. G., Y. L. Lin, and B. A. Askonas. 1982. Immune interferon release when a cloned cytotoxic $T$ cell line meets its correct influenza-infected target cell. Nature (London) 295: $150-152$.

30. Oldstone, M. B. A., R. S. Fujinami, A. Tishon, D. Finney, H. C. Powell, and P. W. Lampert. 1983. Mapping of the major histocompatibility complex and viral antigens on the plasma membrane of a measles virus infected cell. Virology 127:426-437.

31. Palladino, M. A., P. von Wussow, K. T. Pearlstein, K. Welte, and M. P. Scheid. 1983. Characterization of interleukin 2-dependent cytotoxic T-cell clones. IV. Production of alpha, beta and gamma-interferons and interleukin 2 by Lyt $2+\mathrm{T}$ cells. Cell. Immunol. 81:313-322.

32. Pfau, C. J., I. Gresser, and K. D. Hunt. 1983. Lethal role of interferon in lymphocytic choriomeningitis virus-induced encephalitis. J. Gen. Virol. 64:1827-1830.

33. Randrup-Thomsen, A., M. Volkert, and K. Bro-Jorgensen. 1983. Virus elimination in acute lymphocytic choriomeningitis virus infection. Scand. J. Immunol. 17:489-495.

34. Rocklin, R. E., K. Bendtzen, and D. Greineder. 1980. Mediators of immunity: lymphokines and monokines. Adv. Immunol. 29:55-136.

35. Rooperian, D. C., M. B. Widner. C. G. Orosz, and F. H. Bach. 1983. Helper cell independent cytolytic T lymphocytes specific for a minor histocompatibility antigen. J. Immunol. 130:542-545.

36. Sidman, C. L., J. D. Marshall, L. D. Shultz, P. W. Gray, and H. M. Johnson. 1984. Gamma-interferon is one of several direct B cell-maturing lymphokines. Nature (London) 309:801-804.

37. Southern, P. J., and M. B. A. Oldstone. 1984. Studies on the molecular biology of lymphocytic choriomeningitis virus, $p$. 59-64. In R. Compans and D. Bishop (ed.), Segmented negative strand viruses. Academic Press, Inc., New York.

38. Spitalny, G. L., and E. A. Havell. 1984. Monoclonal antibody to murine gamma interferon inhibits lymphokine-induced antiviral and macrophage tumorcidal activities. J. Exp. Med. 159: 1560-1565.

39. Tajiri, K., N. Uchida, and M. L. Tanzer. 1980. Undersulfated proteoglycans are secreted by cultured chondrocytes in the presence of the ionophore monensin. J. Biol. Chem. 365: 6036-6039.

40. Tartakoff, A. M. 1983. Perturbation of vesicular traffic with the carboxylic ionophore monensin. Cell 32:1026-1028.

41. Tartakoff, A. M., and P. Vassalli. 1977. Plasma cell immunoglobulin secretion: arrest is accompanied by alterations of the 
Golgi complex. J. Exp. Med. 146:1332-1345.

42. Tartakoff, A. M., and P. Vassalli. 1978. Comparative studies of intracellular transport of secretory proteins. J. Cell Biol. 79:694-707.

43. Varho, M., F. Lehmann-Grube, and M. M. Simon. 1981. Effector T lymphocytes in lymphocytic choriomeningitis virus-infected mice. J. Exp. Med. 153:992-997.

44. Vignaux, F., and I. Gresser. 1977. Differential effects of interferon on the expression of $\mathrm{H}-2 \mathrm{~K}, \mathrm{H}-2 \mathrm{D}$ and Ia antigens on mouse lymphocytes. J. Immunol. 118:721-723.

45. Watson, J. 1979. Continuous proliferation of murine antigenspecific helper $T$ lymphocytes in culture. J. Exp. Med. 150: 1510-1519.

46. Welsh, R. M. 1978. Mouse natural killer cells: induction, specificity and function. J. Immunol. 121:1631-1635.

47. Welsh, R. M., and M. J. Buchmeier. 1979. Protein analysis of defective interfering lymphocytic choriomeningitis virus and persistently infected cells. Virology 96:503-515.

48. Zinkernagel, R. M., and A. Althage. 1977. Antiviral protection by virus-immune cytotoxic $\mathrm{T}$ lymphocytes: infected target cells are lysed before infectious virus progeny is assembled. J. Exp. Med. 145:644-651.

49. Zinkernagel, R. M., and P. C. Doherty. 1974. Restriction of in vitro $\mathrm{T}$ cell-mediated cytotoxicity in lymphocytic choriomeningitis within a syngeneic or semiallogeneic system. Nature (London) 248:701-702.

50. Zinkernagel, R. M., and P. C. Doherty. 1977. Major transplantation antigens, viruses, and specificity of surveillance $T$ cells. Contemp. Top. Immunobiol. 7:179-220.

51. Zinkernagel, R. M., and P. C. Doherty. 1979. MHC-restricted cytotoxic $\mathrm{T}$ cells: studies on the biological role of polymorphic major transplantation antigens determining $\mathrm{T}$-cell restrictionspecificity, function, and responsiveness. Adv. Immunol. 27:51-177. 